\title{
Improving Community Economy through Hydroponic Vegetable Culture
}

\author{
Christianingrum \\ \{ christianingrum02@gmail.com \} \\ Department of Management, Faculty of Economics, Bangka Belitung University, Bangka Belitung, \\ Indonesia
}

\begin{abstract}
In rural development in the modern era, villages are required to be able to play an active, independent role and be able to fulfill their needs with their own abilities. This is stated in Law No. 06 of 2014 About the Village. The community service program aims to empower the people of Desa Baru, Manggar District, East Belitung Regency as an effort to improve the village economy through fostering vegetable cultivation in hydroponics. The method of activity used in the development of hydroponic vegetable cultivation activities are the lecturing method, discussion and demonstration of the practice of hydroponic vegetable cultivation. The indicators in this study, in general, indicate that there is an increase in participants' knowledge, which shows that when practicing, everything could do independently, could make a simple business plan, be able to explain again when given questions. Participants understand that when their narrow and critical land use is carried out intensively, it could provide benefits for the availability of healthy vegetables and could increase family income.
\end{abstract}

Keywords: Hydroponics, Community Empowerment, Economic Improvement.

\section{Introduction}

Hunger and poverty are common problems that occur in any country including Indonesia. Many solutions have been implemented by the Indonesian government to overcome this problem, one of which is the development of the agricultural sector. Hydroponics is one of the planting techniques to increase the quality and quantity of plants in infertile and narrow areas. Baru Village is a village located not far from the coastal area. The majority of the population is fishermen who fulfill their needs from resources on the coast. People living in coastal areas are traditional fishermen who, because of their unworthiness in all aspects, both material, knowledge and technology, make them poor and disadvantaged. The source of people's livelihood is very dependent on natural conditions (weather). In addition, the yard in the community housing area is still left unchecked. The people's agricultural land has not been utilized and only a few are used to grow cassava. Horticulture plants are very minimal in this area, especially plants that can be used as vegetables are not cultivated in this area. This resulted in the need for vegetables to be brought in from other regions, and the price of these vegetables became expensive. In fact, the fulfillment of family food needs can be done in the field using a hydroponic cultivation system [1].

Hydroponics is one of the technologies of plant cultivation that does not rely on land as a planting medium [2]. The advantages of plant cultivation with hydroponic systems are 
efficient land use for plant growth, better production, easy maintenance and plants can grow quickly easily [3]. The requirement is that nutritional needs for plants are fulfilled and with enough sunlight [4]. This hydroponic activity was appointed in the community service program because vegetable consumption in Indonesia is still low at $40.35 \mathrm{~kg} / \mathrm{capita}$ per year. This is lower than the people of Vietnam and Singapore which reached more than $100 \mathrm{~kg} / \mathrm{year}$ [5]. The hydroponic technique of the wick system is one of the simplest hydroponic systems and is used by beginners. According to [6]. The hydroponic wick system is very suitable for beginners who want to grow by means of hydroponics, because of its basic principles and limited land use. According to [7], other advantages of the wick system are that they do not require special maintenance, are easy to assemble, portable (can be moved), and are suitable on limited land.

In general, the problems faced by the community in carrying out hydroponic planting activities are still experiencing several obstacles such as the lack of information on good farming methods. This is also due to getting information that has to go outside the village and requires considerable costs, besides the lack of training in planting media, the provision of organic fertilizers from surrounding materials and the utilization of waste and materials around as pots or planting containers. This has an impact on the development of activities of the Baru Village community to be able to grow crops, especially hydroponics. This will certainly hamper developments in the development of the New Village which has great potential to be developed.

\section{Text formatting}

There are several types of indicators including: Stochastic, MACD and Bollinger Bands [1], Moving Avarage [2], and Relative Strength Index (RSI) [3]. This research will use a new indicator developed by Ahmar i.e. Sutte Indicator (SUTTE) [4]. Sutte Indicator is technical indicators developed by considering the stock price at the time of opening, closing, highest and lowest. Sutte Indicator will form two graphs that show stocks when looking for suitable stock buy and when to sell. This graph is intended to provide a signal to investors to get maximum profit with minimal losses. In predicting stock, Sutte indicators will be compared with other technical analysis is Simple Moving Average (SMA) dan Moving Average Convergence/Divergence (MACD). The formula SUTTE, SMA and MACD are presented as follows.

\section{Methodology}

Service activities were carried out in Baru Village, Manggar District, East Belitung Regency. The implementation of programs and activities in the field is carried out from July to August 2018. The target audience in this activity is the community and village officials from each hamlet and RT, as well as housewifes in the New Village. While the Agriculture and Food Service and UPTD East Belitung hatchery are partners in implementing this activity. The method of activity used in the development of hydroponic vegetable cultivation activities are the lecturing method, discussion and demonstration of the practice of hydroponic vegetable cultivation. The lecturing method to explain the material during the training to the 
target audience as an effort to improve their knowledge and skills, and combined with the discussion method in the form of question and answer related to the material presented. The method of practice and assistance is carried out as a follow-up to training activities aimed at improving the technical skills of the target audience.

\section{Result and Discussion}

This community service activity began with observations and initial discussions with the community in Baru Village, Manggar District. This initial discussion was directed at identifying problems faced by residents, registering the whereabouts of residents and discussing the wishes of residents about how to grow crops, what work groups had been running in the village. From this initial meeting, data was obtained that actually the community had utilized the land by planting a system of tabula pot or plants and flowers in pots. Planted plants tend to be ornamental plants and some also plant crops for daily needs such as red pepper.

The geographical location of Baru Village which is close to the coast causes the land in the village tend to sand so that it has limited topsoil which is not suitable for farming. Therefore, many people in the Baru Village who work as fishermen and their housewife are members of joint business groups. Where the efforts of these housewife tend to process sea products and also processed from breadfruit. Based on the results of observations of the problems that exist in the New Village as a form of dedication to real work college students at the University of Bangka Belitung, they want to introduce the community how to grow the hydroponic system. From this activity the community will be able to develop the knowledge they have gained to make hydroponics their business.

Information and Coaching Activities After the assessment was carried out through discussion and observation of the Baru Village community, the next activity of community service was socialization and guidance to the community on how to cultivate with the hydroponic system. This activity was carried out in the field by setting up meeting tents. This is done because the hydroponic sample (Figure 1.) made by the team is very unlikely to be carried out if this activity is carried out at the village hall which is located quite far from the location, besides remembering the practice of how to grow hydroponics requires space where the floor is not slippery and close to the water tap.

In the implementation of this activity the first session was carried out by the resource person and then continued by Mr. Hasbullah as the hydroponic practitioner from the UPTD Hatchery who was directly supervised by the Agriculture and Food Service of East Belitung Regency. Then in the next session the participants practiced directly from preparing the planting media, preparing plant seeds, preparing paralon pipes / Styrofoam used fruit, directing further actions that must be done by the participants after the seedlings were sown. Briefly, the steps undertaken by participants during hydroponic vegetable farming practices (wick technique) are as follows:

a) Tools and materials:

1. Styrofoam used fruit as a nutrient reservoir

2. Net Pot, Styrofoam, rockwool, vegetable seeds, AB mix nutrition 
b) Steps:

1. Styrofoam is given a hole with a diameter in accordance with the net pot, then cut the rockwool into cubes $2.5 \times 2.5 \mathrm{~cm}$ in size, then rockwool is soaked briefly with water and then lifted and flicked.

2. Make a hole for the seed on rockwool using a toothpick, then lift the seed with a toothpick, place it on the rockwool hole that has been made. After finishing the seed is covered with black plastic to avoid the light

3. When the seeds have broken or sprout, the seeds are dried in the sun and watered periodically to keep the rockwool from drying out. When the plant has four leaves, it can be given nutrients

4. Prepare clean water in the container for providing nutrition with a note in every one liter of water, add $5 \mathrm{ml}$ of Nutrition A and $5 \mathrm{ml}$ of Nutrition B. Then prepare a netpot, and place the plants in the netpot then put into styrofoam holes.

The participants were very enthusiastic. It was seen that they had prepared notes and asked a few questions. Evidence of the enthusiasm of the community following this training was seen since the commencement of the activity until the end of this activity, where the participants were willing to leave their homework to take part in this activity. At the end of the material delivery session, participants were given vegetable seeds so that later they could practice on their own in their homes.

\subsection{Indicator of Activity Success}

After conducting socialization and guidance in community service, the next step is the evaluation of activities. The method of evaluation is to compare the knowledge and understanding of participants before and after socialization and guidance both for how to cultivate hydroponics, manufacture fertilizers and for entrepreneurship and marketing materials. Participants understand that when their narrow and critical utilization is carried out intensively, it can provide benefits for the availability of healthy vegetables and can increase family income. In general, there is an increase in participants' knowledge, which is shown when all practices can be done independently, can make a simple business plan, be able to explain back when given questions. Table 1 below shows the criteria and indicators for the success of this community service activity.

Table 1 Indicator of the success of activities

\begin{tabular}{lll}
\hline No & \multicolumn{1}{c}{ Criteria } & \multicolumn{1}{c}{ Indicator } \\
\hline 1 & $\begin{array}{l}\text { Level } \\
\text { Participation }\end{array}$ & $\begin{array}{l}\text { This Outreach and Coaching activity exceeds the expected number } \\
\text { of target participants. }\end{array}$ \\
2 & $\begin{array}{l}\text { Level of participants' } \\
\text { understanding of the } \\
\text { material } \\
\text { Training }\end{array}$ & $\begin{array}{l}\text { Reflected the process of increasing understanding of fit hydroponic } \\
\text { planting. Active participants in discussions, question and answer, } \\
\text { express ideas and be able to practice well. The participants were } \\
\text { very serious and enthusiastic to follow from the beginning of the } \\
\text { event to completion. }\end{array}$ \\
& $\begin{array}{l}\text { Impact } \\
\text { counseling }\end{array}$ & $\begin{array}{l}\text { Participants are able to practice hydroponic farming methods, and } \\
\text { can mix nutrition for hydroponics and have ideas about how to } \\
\text { market the products produced. }\end{array}$ \\
\hline
\end{tabular}




\begin{tabular}{lll}
\hline No & Criteria & \multicolumn{1}{c}{ Indicator } \\
\hline 4 & Suitability Material & $\begin{array}{l}\text { n the opinion of the participants, the training material is very } \\
\text { contemporary (hydroponics is a trend and is able to provide } \\
\text { organic food). Straightforward and communicative delivery } \\
\text { methods make it easier and interesting for participants to follow } \\
\text { and understand entrepreneurship and marketing material. }\end{array}$ \\
\hline
\end{tabular}

The arrangement of the program made very flexible and the provision of the right material both time and place felt very supportive of the activity, where participants had a lot of time to attend this hydroponic socialization and training comfortably to the end.

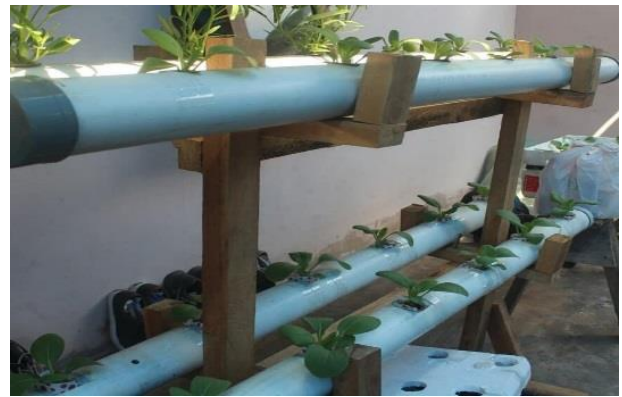

Fig. 1. Hydroponic Wick system for vegetable

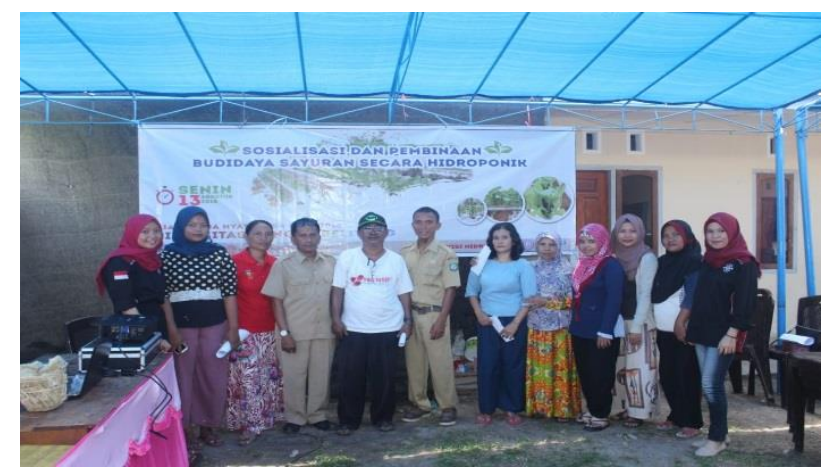

Fig. 3. Socialization for hydroponic Wick system

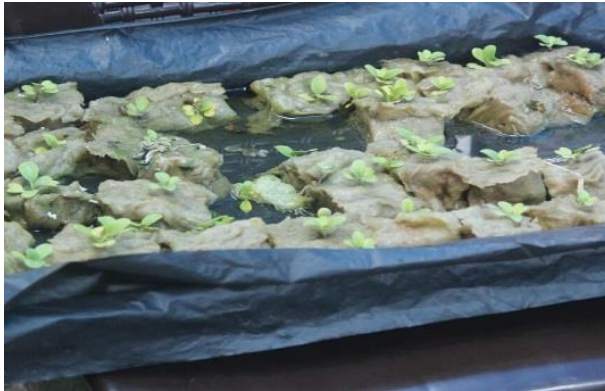

Fig. 2. Seedling of vegetable for hydroponic

\subsection{Driving and Inhibiting Factors of Activities}

In general, this service activity was successful when viewed from several of the above mentioned indications. There were several factors that contributed to the success of this event, which was designed with high involvement from the service partners, namely the East Belitung District Agriculture and Food Service who had provided tools and materials for hydroponics. These problems are raised and identified obtained directly so that the citizens are very enthusiastic when participating in each stage of community service. Speakers who 
provide socialization and coaching have good communication skills so that they can be integrated with participants both formally and informally, besides those concerned are people who truly master science and practice.

The inhibiting factor is hydroponic nutrition in the form of $\mathrm{AB}$ mix which is difficult to obtain in the area of East Belitung. AB mix is a nutrient used in hydroponic systems. This fertilizer consists of two parts, namely stock A in the form of macro nutrients while stock B is in the form of micro nutrients. $\mathrm{AB}$ Mix is able to provide nutrients needed by plants because it can be absorbed well by roots and has sufficiently complete nutrients for hydroponic cultivation [8]. In addition, the start time of activities that are backward is due to the culture of people who often buy time.

\section{Conclusion}

From the results of the activities that have been carried out, it can be concluded that:

a) This service activity can increase people's knowledge about the importance of using the land through hydroponic cultivation.

b) The New Villagers are highly motivated to become new entrepreneurs in the field of hydroponic agribusiness.

c) Basically, the Desa Baru community has begun to use their narrow plot of land with tabula pot, so the training activities are focused on how to cultivate hydroponics and increase insights on marketing management and entrepreneurship.

\section{Acknowledgments}

The author expresses his deepest gratitude[9][10] to the University of Bangka Belitung for facilitating community service activities through the Real Work Lecture program, one of which is this paper. Do not forget to thank the Department of Agriculture and Food of East Belitung Regency for facilitating training and support activities in providing assistance for tools for Hydroponic activities[11]. Furthermore, the authors would like to thank the parties who helped so that this article was presented at the 2018 National Community Service Symposium held by HSBC Indonesia in collaboration with Sampoerna University supported by Indonesian Journal Volunteers[12].

\section{References}

[1] Prayoga, Gigih Ibnu. 2016. Optimization of Yard for Agriculture in Jada Bahrin Village, Merawang District, Bangka Regency, Bangka Belitung Islands Province. Community Service Journal of the University of Bangka Belitung. Vol 3 (1): 39-47.

[2] Perwitasari B, Tripatmasari M, Wasonowati C. 2012. Effect of Planting Media and Nutrition on Growth and Yield of Pakchoi (Brassica Juncea L.) Plants with Hydroponic Systems. AGROVIGOR. 5 (1): 14-25.

[3] Hartus, Tony. 2008. Cheap Hydroponic Gardening IX Edition. PT. Agromedia Library: Jakarta. 96p.

[4] Alhadi DGD, Triyono S, Haryono N. 2016. Effect of Use of Multiple Colors of Neon Lights on Kailan Plant Growth (Brassica oleraceae) in Indoor Hydroponic Systems. Lampung Agricultural Engineering Journal. Vol5 (1): 13-24. 1 
[5] Latifah E, Boga K, Mariyono J. 2014. Introduction of the School Vegetable Garden Model for Increasing Vegetable Consumption for Students in Kediri - East Java. Agrieconomics. Vol 3 (1): 421-431. 6

[6] Tintondp. 2015. Hydroponic Wick System: The Most Practical Ways to Harvest. PT. Agromedia Library: Jakarta. 78p. 12

[7] Marlina I, Tusi A. 2015. Effect of Media Planting Granules from Clay on Vegetable Growth in Hydroponic Axis Systems. Lampung Agricultural Engineering Journal. 4 (2): 143-150.

[8] Sundari, Raden I, Hariadi US. 2016. Effect of POC and AB Mix on Growth and Yield of Pakchoy (Brassica chinensis L.) Plants with Hydroponic Systems. Magrobis Journal. Vol 16 (2): 9-19. 11

[9] Dwiratna, Widyasanti, Rahmah. 2016. Utilization of Yard Land by Implementing the Sustainable Food House Area Concept. Science and Technology Application Journal for Society. Padjadjaran University. Vol. 5. No. 1. May 2016. 2

[10] Ema Nurzainul Hakimah, et al. 2017. Community Empowerment Through Hydroponic Training Forms New Entrepreneurs in North Kuwak Housing, Ngadirejo Village, Kediri City. ABDINUS Journal. Universitas Nusantara PGRI. Vol.1. Number 1. 2017.

[11] Hendra Saputra, et al. 2018. Hydroponic Tourism Village as an Effort to Empower the Community of Sidumulyo Village, Anggana District, Kutai Kartanegara Regency. Community Service Journal. Mulawarman University. Vol. 24. Number 1. 2018.

[12] Stevanus G. Kaunang. Et al. 2016. Community Perception of Hydroponic Plants in Lotta Village, Pineleng District, Minahasa Regency. Agri-Socioeconomic Journal. Unsrat. Vol. 12. No.2A. 10 